\title{
Livskvalitet og komorbiditet hos barn med tvangslidelse
}

\author{
Barn og ungdom med tvangslidelse har redusert livskvalitet, men etter \\ behandling med kognitiv terapi er livskvaliteten like bra som i den gene- \\ relle populasjonen.
}

Tvangslidelse (OCD) forekommer hos $1-3 \%$ av barnebefolkningen og fører ubehandlet til et kronisk forløp hos to tredeler. Rundt $80 \%$ har minst én komorbid tilstand. $\AA$ utforske livskvalitet hos barn og unge med tvangslidelse er relevant fordi det finnes et stort antall studier av livskvalitet hos voksne med tilstanden, men svært få undersøkelser hos barn.

Mitt doktorgradsarbeid var en del av en nordisk multisenterstudie, der vi blant annet målte livskvalitet hos barn og ungdom med tvangslidelse som ble behandlet med kognitiv atferdsterapi med eksponering. Livskvalitet før behandling var tydelig redusert, og hos barn med komorbide lidelser beskrev foreldrene lavere livskvalitet enn hos dem med bare tvangslidelse. $72 \%$ av deltakerne responderte på behandlingen. Etter behandlingen rapporterte respondere en livskvalitet på samme nivå som i den generelle befolkningen, mens de som ikke hadde effekt rapporterte ingen forbedring.

Organisasjoner som Verdens helseorganisasjon og U.S. Food and Drug Administration anbefaler å ha med vurdering av livskvalitet både som behandlingsmål og som del av effektevalueringen for behandlingsprogrammer, spesielt ved lidelser der enkelte symptomer kan vedvare etter behandlingen. Å inkludere livskvalitetsevaluering som et mål for barns og foreldres subjektive opplevelse bidrar til en mer helhetlig forståelse av tvangslidelser hos barn og unge. Erfaringene fra studien resulterte også i publisering av en behandlingsmanual for tvangslidelser hos barn og unge.

\section{Bernhard Weidle}

b-weidle@online.no

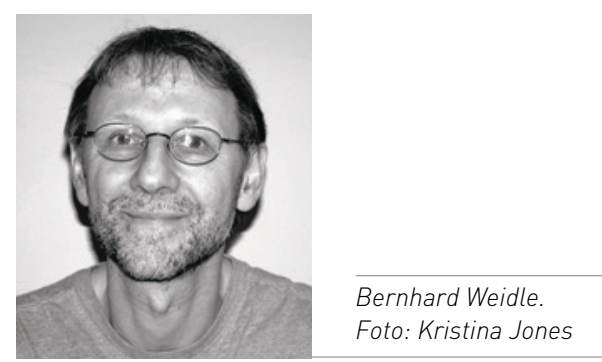

Disputas

Bernhard Weidle disputerte for ph.d.-graden ved Norges teknisk-naturvitenskapelige universitet 9.1. 2015. Tittelen på avhandlingen er Children and adolescents with obsessive-compulsive disorder: comorbidity and quality of life.

\section{Familiebehandling av barnefedme}

\section{Flerfamilietilbud ga noe bedre effekt på midjemål og grad av overvekt enn enkeltfamilietilbud.}

Vi har begrenset kunnskap om langtidseffekter av barnefedmeprogram (> 1 år), inkludert behandlingens effekt på psykisk helse. Dessuten savnes informasjon om kostnadsnyttige barnefedmeprogram som kan brukes i primærhelsetjenesten.

Blant førskolebarn født 1999-2000 hadde $16 \%$ av guttene og $22 \%$ av jentene overvekt eller fedme. Det viste data samlet inn fra helsestasjoner i Finnmark. I behandlingsstudien Aktivitetsskolen i Finnmark ble 97 familier fra seks kommuner i Finnmark og Tromsø kommune loddtrukket til enkeltfamilie- eller flerfamilietilbud. Enkeltfamilietilbudet besto av møte med sykepleier, barnelege og klinisk ernæringsfysiolog på barnepoliklinikk samt oppfølging hos helsesøster. For barna i flerfamilietilbudet ble det i tillegg utført rådgivning av flerfaglig team på barneavdeling og av helsesøster i grup- per, det ble organisert ukentlig treningstilbud og en friluftsskole for familiene. Etter to år var det en beskjeden forskjell i favør av flerfamilietilbudet i endring av kjønnsog aldersjustert kroppsmasseindeks (BMI) $(p=0,046)$, midjemål $(p=0,038)$, men ingen forskjell $\mathrm{i}$ utvikling i ren BMI $(p=0,075)$. Begge gruppene samlet viste reduksjon av overvekt og bedring i psykisk helse.

Flerfamilietilbudet kan synes noe mer effektivt, men var også mer ressurskrevende. Samlet kan resultatene tyde på at kompetanseheving, systematisk samarbeid mellom første- og annenlinjetjeneste og løsningsfokusert veiledning har vært til hjelp for familier i begge grupper.

Ane Sofie Kokkvoll

ane.kokkvoll@finnmarkssykehuset.no

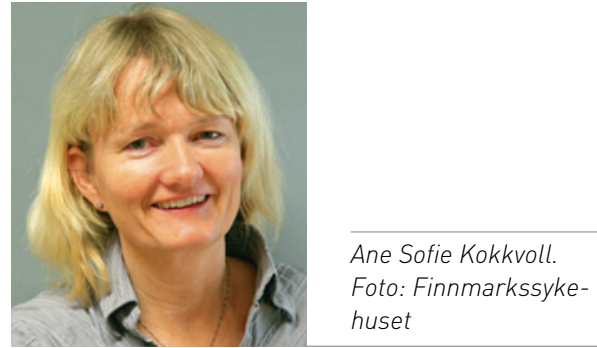

Disputas

Ane Sofie Kokkvoll disputerte for ph.d.-graden i medisinske fag ved Universitetet i Troms $\varnothing$ Norges arktiske universitet 11.12. 2014. Tittelen på avhandlingen er: Managing childhood obesity. The Finnmark Activity School 